\title{
Occurrence of Vibrio spp. along the Algerian Mediterranean coast in wild and farmed Sparus aurata and Dicentrarchus labrax
}

\author{
Sonia Arab $^{1}$, Luca Nalbone ${ }^{2}$ (D), Filippo Giarratana2 ${ }^{2}$ and Ali Berbar ${ }^{1}$ \\ 1. Institut des Sciences Vétérinaires, Laboratoire de Recherche de Biotechnologies liées à la Reproduction Animale, \\ University of Saad Dahlab - Blida, route de Soumâa BP 270, Blida, 09000, Algeria; 2. Department of Veterinary Sciences, \\ University of Messina, Polo Universitario dell'Annunziata, 98168 Messina, Italy. \\ Corresponding author: Filippo Giarratana, e-mail: fgiarratana@unime.it \\ Co-authors: SA: soniaveto1@gmail.com, LN: Inalbone@unime.it, AB: berbarali@yahoo.fr \\ Received: 29-01-2020, Accepted: 05-05-2020, Published online: 26-06-2020
}

doi: www.doi.org/10.14202/vetworld.2020.1199-1208 How to cite this article: Arab S, Nalbone L, Giarratana F, Berbar A (2020) Occurrence of Vibrio spp. along the Algerian Mediterranean coast in wild and farmed Sparus aurata and Dicentrarchus labrax, Veterinary World, 13(6): 1199-1208.

\begin{abstract}
Background and Aim: Vibrio bacteria are autochthonous inhabitants of aquatic and marine environments. Certain strains are responsible for important seafood-borne outbreaks in developed nations. The aim of this study was to investigate the occurrence of Vibrio spp. along the Algerian Mediterranean coast in several samples of two prominent wild and farmed marine fishes, Sparus aurata and Dicentrarchus labrax.
\end{abstract}

Materials and Methods: A total of 350 S. aurata $(n=280$ farmed and $n=70$ wild) and 340 D. labrax ( $=250$ farmed and $\mathrm{n}=90$ wild) were sampled among three different locations along the Algerian Mediterranean coastal area. The samples were processed for Vibrio research according to the ISO methods. Isolated colonies were identified utilizing biochemical tests and consecutively confirmed with matrix-assisted laser desorption ionization-time-of-flight mass spectrometry, combined with polymerase chain reaction (PCR) analysis when appropriate, or confirmed with PCR analysis alone.

Results: A total of 42 Vibrio spp. were detected only among the farmed fishes. Taking into account, all 690 fishes sampled, the incidence of Vibrio spp. was $6.08 \%$ (with peaks up to 7.92\%) among the total number of farmed fishes. Overall, 25 strains were isolated from $S$. aurata and 17 strains were isolated from D. labrax. The isolated strains belonged to four different species and were represented as follows: Vibrio alginolyticus $(\mathrm{n}=20)$, Vibrio cholerae $(\mathrm{n}=15)$, Vibrio fluvialis $(\mathrm{n}=5)$, and Vibrio hollisae $(\mathrm{n}=2)$. The incidence of Vibrio was higher in places characterized by greater levels of anthropogenic contamination of seawater.

Conclusion: Considering the growing production and consequent rising consumption of farmed fish in Algeria, the reported incidence of Vibrio and the presence of potentially pathogenic strains of Vibrio such as V. cholerae cause particular concern for food safety matters. Even if innovative and natural techniques are desired in aquaculture, proper hygiene and manufacturing practices are essential for the correct management of Vibrio infection risk in farmed fishes at both industrial and domestic levels.

Keywords: Algeria, gilt head sea bream, Mediterranean sea, sea bass, Vibrio spp.

\section{Introduction}

Bacteria comprising the genus Vibrio are known to be autochthonous inhabitants of aquatic and marine environments, as well as waterborne bacterial pathogens [1-3]. Of the genus Vibrio, the most widely studied species is Vibrio cholerae, the etiological agent of cholera $[4,5]$. However, in recent years, more attention has been paid to other potentially enteropathogenic Vibrio spp. such as Vibrio vulnificus and Vibrio parahaemolyticus as the strains in question have emerged as the predominant etiological agents of human seafood-borne infections in developed nations [4,6-12]. To date, there are more than 100 individual species in

Copyright: Arab, et al. Open Access. This article is distributed under the terms of the Creative Commons Attribution 4.0 International License (http://creativecommons.org/licenses/by/4.0/), which permits unrestricted use, distribution, and reproduction in any medium, provided you give appropriate credit to the original author(s) and the source, provide a link to the Creative Commons license, and indicate if changes were made. The Creative Commons Public Domain Dedication waiver (http://creativecommons.org/ publicdomain/zero/1.0/) applies to the data made available in this article, unless otherwise stated. the genus Vibrio, but only approximately a dozen have been associated with human illness [4]. Among these pathogenic strains, Vibrio alginolyticus, V. cholerae, Vibrio costicola, Vibrio mimicus, Vibrio cincinnatiensis, Vibrio hollisae, Vibrio fluvialis, Vibrio furnissii, $V$. parahaemolyticus, V. vulnificus, Vibrio carchariae (a junior synonym of Vibrio harveyi), and Vibrio metschnikovii are clinically important as they are capable of causing several types of vibriosis related to the ingestion of contaminated water and undercooked seafood [4,8,13-18]. The pathogenicity of Vibrio is reported not only within humans but also within several aquatic organisms [19-22]. In fact, Vibrio aguillarum and $V$. alginolyticus are found present as pathogens in several fishes and shellfishes $[16,21,22]$. $V$. alginolyticus is responsible for many epizootic outbreaks in the two most important fish of Mediterranean aquaculture such as gilthead sea bream (Sparus aurata) and sea bass (Dicentrarchus labrax) [19,20,23].

The incidence and occurrence of Vibrio infections in humans are on the rise worldwide $[4,6,7,17,24,25]$. 
This worldwide spread of Vibrio is most likely related to several factors such as (i) climate change variations [11,12,26,27]; (ii) new oceanic patterns that introduce warmer waters into colder regions and change the salinity profile of coastal rivers [11,12,26,28]; (iii) the rising consumption of seafood products, especially raw or undercooked seafood [6,14,29-32]; and (iv) an increase in nutrients such as nitrogen and carbon stemming from coastal anthropization and the presence of fish farms and bathing facilities [18,31,33,34].

As reported above, considering the widespread and growing economic importance of marine fish farming for Algeria (a projection of 100,000 tons of seafood a year by 2020) $[35,36]$ and the lack of data on the presence of pathogenic Vibrio for the country in question, which has been thoroughly described in wild and farmed fishes [20,37-40]. The aim of this study was to investigate the occurrence of Vibrio spp. along the Algerian Mediterranean coast in the two most important cultured and wild marine fish in Algeria, S. aurata and D. labrax.

\section{Materials and Methods}

\section{Ethical approval}

This study does not contain any experimental studies with animals. All fishes used were just died before sampling.

\section{Fishes collection}

The present survey was conducted monthly for 2 consecutive years (from January 2017 to December 2018), collecting a total of 690 wild and cultured sea bass (D. labrax) and gilt head sea bream (S. aurata) along the coast of the Algerian Mediterranean (Tables-1 and 2). Three different locations (Boumerdes, Azefoune, and Tipaza) were selected in relation to the proximity of fish farms and commercial fishing activity in the vicinity (Figure-1).

All the fishes examined in this study were selected among fishes with commercial dimensions (weighing at least $300 \mathrm{~g}$ ). Farmed fishes, immediately after being harvested, were killed by immersion in an ice-water slurry.

All wild fishes, which were fished close to the relative area, were harvested directly from local fishermen within 4-6 $\mathrm{h}$ after their catch period.

In the Boumerdes area, a total of 420 fishes were collected: 340 cultured fishes from the two fish farms (F1 and F2) were present and 80 wild fishes were also present (40 sea bream and 40 sea bass). Regarding cultured fishes, 260 fishes (100 S. aurata and 160 D. labrax) were sampled from F1 (Cap Djinet, Algeria), while the remaining 80 fishes (only $S$. aurata) were sampled from F2 (Zemmouri, Algeria). Farm F1 was a land-based fish farm that takes in the waters of Isser Wadi alongside absorbing the hot water discharged by the Cap Djinet thermal power plant; farm F2 was, in contrast, an offshore plant. The untreated sewage discharge from the town of Zemmouri flows into the seawater of the Boumerdes area.

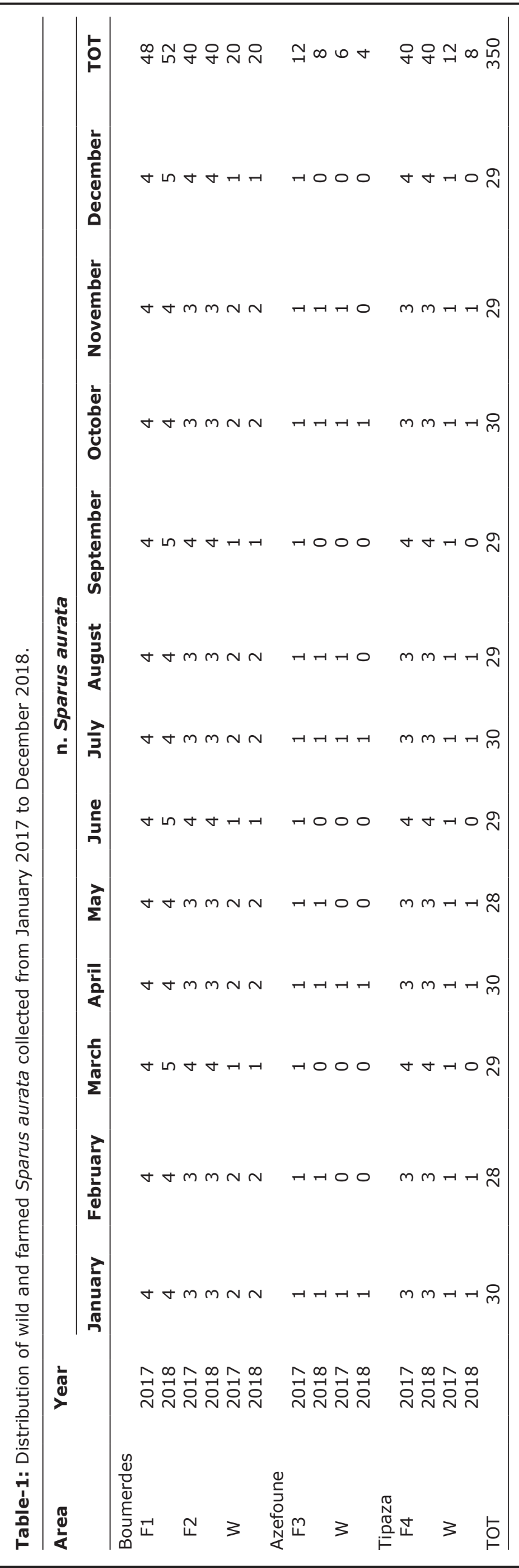

Veterinary World, EISSN: 2231-0916 


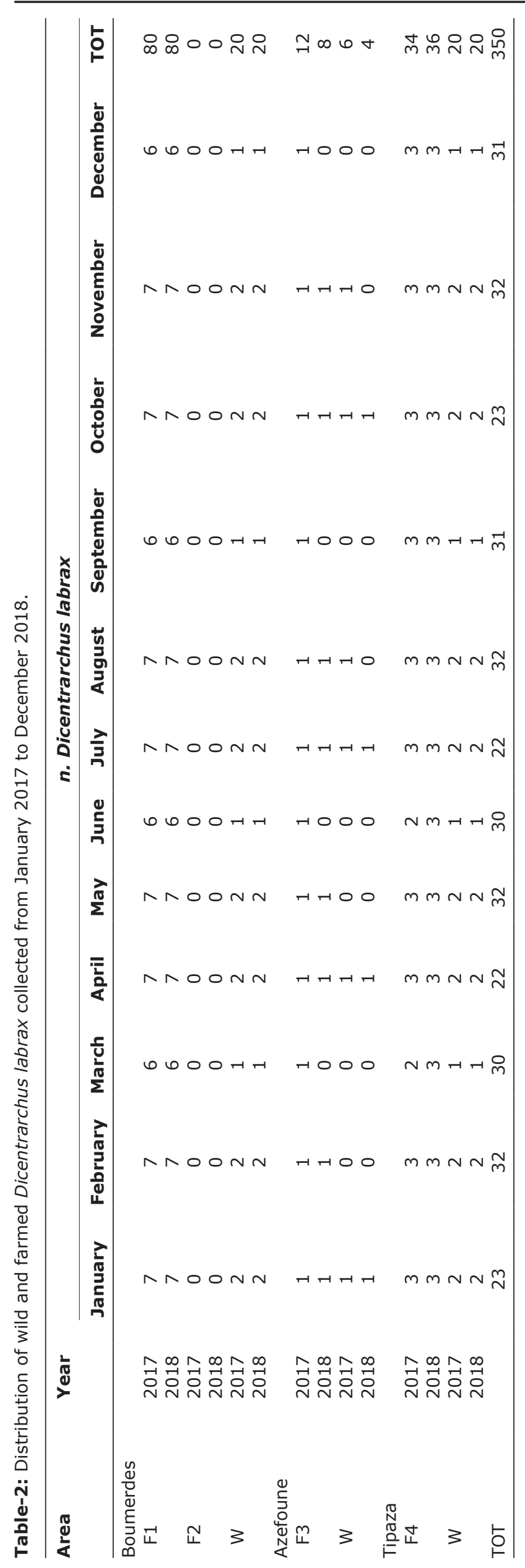

In the Azefoune area, a total of 60 fishes were collected: 40 cultured fishes (20 sea bream and 20 sea bass) were harvested from the fish farm F3 and 20 wild fishes (10 sea bream and 10 sea bass). Farm F3 was an offshore aquaculture area (F3), placed in a location close to Irzer M'lata Wadi.

Finally, the remaining 210 fishes were harvested from the Tipaza area: 150 cultured fishes ( 80 sea bream and 70 sea bass) were collected from the offshore fish farm F4 and 60 wild fishes (20 sea bream and 40 sea bass) were also collected. This area absorbed the untreated wastewater discharges from the industrial group of the town of Ain Tagourait.

\section{Bacteriological analysis}

Once they were successfully collected, all fishes were transported to the laboratory of the Institute of Veterinary Sciences of the University of Saad Dahlab (Blinda, Algeria) in single, clean plastic containers under refrigerated condition $\left(2-4^{\circ} \mathrm{C}\right)$ and immediately analyzed. Materials were harvested from each fish: Skin, gills, and intestinal content were aseptically all removed and rendered into small pieces utilizing sterile forceps and scalpels. The obtained mixture was divided into two aliquots: The first aliquot for the detection of $V$. parahaemolyticus and $V$. cholerae according to ISO/TS 21872-1: 2007 [41] and the second aliquot for the detection of other Vibrio species according to ISO/TS 21872-2: 2007 [42].

\section{Detection of $\boldsymbol{V}$. parahaemolyticus and $\boldsymbol{V}$. cholerae}

Alkaline saline peptone water (ASPW) (2\% of $\mathrm{NaCl}$ with a final $\mathrm{pH}$ of $8.6 \pm 0.2)$ at ambient temperature was combined with a ratio of $1: 9(\mathrm{w} / \mathrm{v})$ with the obtained mixture of fish skin, gills, and intestinal content (from 10 to $25 \mathrm{~g}$ ) and homogenized for $60 \mathrm{~s}$ at $230 \mathrm{rpm}$ utilizing a stomacher. After an incubation period at $41.5^{\circ} \mathrm{C}$ for $6 \pm 1 \mathrm{~h}, 1 \mathrm{ml}$ from this first enrichment in ASPW was inoculated into a tube containing $10 \mathrm{ml}$ of ASPW (second enrichment - incubation at $41.5^{\circ} \mathrm{C}$ for $18 \pm 1 \mathrm{~h}$ ) and simultaneously streaked with a sampling loop on the surface of thiosulfate citrate bile sucrose agar (TCBS - with $1 \% \mathrm{NaCl}$ and incubated at $37^{\circ} \mathrm{C}$ per $24 \pm 1 \mathrm{~h}$ ) (bioMerieux, Marcy l'Etoile, France). The second enrichment was also streaked with a sampling loop on TCBS and incubated in the same fashion.

From the two TCBS plates, at least five colonies of Vibrio considered to be typical or similar to V. cholerae (smooth, green, and with a diameter of 2-3 $\mathrm{mm}$ ) and to V.parahaemolyticus (smooth, yellow, and with a diameter of 2-3 $\mathrm{mm}$ ) were chosen and plated on saline nutrient agar (SNA with $1 \% \mathrm{NaCl}$ incubated at $37^{\circ} \mathrm{C}$ for $24 \pm 3 \mathrm{~h}$ ) (bioMerieux, Marcy l'Etoile, France).

\section{Detection of other Vibrio species}

With respect to the process previously described according to ISO/TS 21872-2: 2007 [42], for the detection of other Vibrio species, it was necessary to alter only the temperature of incubation of the second aliquot in the two required enrichments in ASPW. In particular, the first enrichment necessitated an 


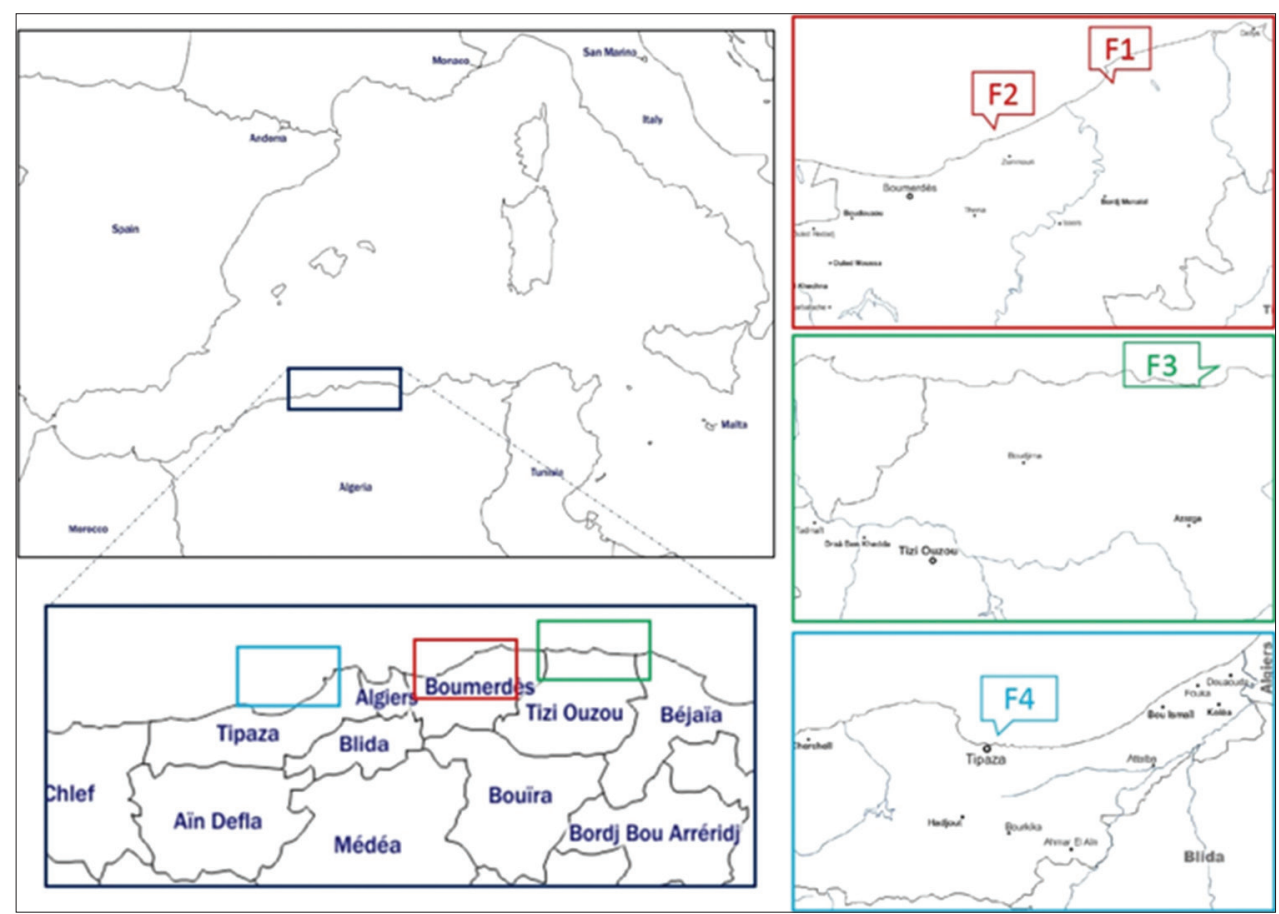

Figure-1: Localization of sampling area along the Mediterranean Algerian coast. In red, the Boumerdes with two fish farms $\mathrm{F} 1$ and $\mathrm{F} 2$; in green, the Azefoune area with the fish farm F3; in blue, the Tipaza area with fish farm F4.

incubation at $37^{\circ} \mathrm{C}$ for $6 \pm 1 \mathrm{~h}$, while the second aliquot was incubated at $37^{\circ} \mathrm{C}$ for $18 \pm 1 \mathrm{~h}$.

From the two TCBS plates, at least five colonies considered to be typical (smooth, green, or yellow and with a diameter of 2-3 $\mathrm{mm}$ ) were chosen and plated on SNA with $1 \% \mathrm{NaCl}$ incubated at $37^{\circ} \mathrm{C}$ for $24 \pm 3 \mathrm{~h}$.

\section{Biochemical identification}

All presumptive colonies isolated on SNA underwent an oxidase test (bioMerieux, Marcy l'Etoile, France) as well as morphology, mobility, and Gram reactions utilizing microscopes. Only the oxidase-positive and Gram-negative colonies which yielded positive results in the motility test were then tested for the following biochemical confirmations: Arginine dihydrolase (bioMerieux, Marcy l'Etoile, France), L-lysine decarboxylase (bioMerieux, Marcy l'Etoile, France), and ornithine decarboxylase (bioMerieux, Marcy l'Etoile, France) and then underwent evaluation of growth in peptone water with increasing salt $(\mathrm{NaCl})$ concentrations $(0 \%, 2 \%, 4 \%, 6 \%, 8 \%$, and $10 \%)$ incubated at $37^{\circ} \mathrm{C}$ for $24 \pm 3 \mathrm{~h}$. The remaining colonies required biochemical confirmations such as detection of $\beta$-galactosidase, of indole, and tests with saline TSI agar were instead performed with an API 20E commercial kit (bioMerieux, Marcy l'Etoile, France). The confirmation of Vibrio species identification obtained according to ISO/TS 21872-1: 2007 [41] and ISO/TS 21872-2: 2007 [42] as well as of unreported species was finally performed according to the Noguerola and Blanch biochemical identification key [43].

\section{Confirm of identification}

The obtained identifications utilizing biochemical tests were confirmed with matrix-assisted laser desorption ionization-time-of-flight mass spectrometry (MALDI-TOF MS) alone, a mix of MS and polymerase chain reaction (PCR) when necessary or PCR alone. These analyses were performed in the Food Inspection Laboratory of the Department of Veterinary Sciences at the University of Messina, Italy. Once the strains arrived at the laboratory, they were plated on Nutrient Agar (Biolife, Milan, Italy) or on SNA (with $2 \% \mathrm{NaCl}$ ) for non-halophilic and halophilic Vibrio, respectively, and incubated at $37^{\circ} \mathrm{C}$ for $24 \mathrm{~h}$.

In addition, all the Vibrio strains were stored at $-80^{\circ} \mathrm{C}$ in Brain Heart Infusion (Biolife, Milan, Italy) plus $15 \%$ of glycerol (Biolife, Milan, Italy) supplemented with $1 \% \mathrm{NaCl}$.

\section{MALDI-TOF MS identification}

For MALDI-TOF MS identification, Vibrio colonies cultured on NA or on SNA (with $2 \% \mathrm{NaCl}$ ) were directly transferred utilizing a loopful ( $1 \mu$ l loop) on FlexiMass MALDI target plates, with 48-well sample spots (bioMerieux, Firenze, Italy). Each colony was smeared into a thin film on a single well, overlaid with $1 \mu \mathrm{l}$ of matrix solution (CHCA, saturated solution of alpha-cyano-4-hydroxycinnamic acid in $500 \mathrm{~mL} / \mathrm{L}$ acetonitrile, and $25 \mathrm{~mL} / \mathrm{L}$ trifluoroacetic acid) and air-dried for $5 \mathrm{~min}$ at room temperature. Escherichia coli ATCC 8739, utilized as calibrator and internal ID control, and grown in blood agar $(50 \mathrm{~mL} / \mathrm{L}$ sheep blood) (Biolife, Italy) for $24 \mathrm{~h}$, was inoculated on distinct and separate calibration spots (G3 and G4 position). After crystallization of the matrix and microbial material, the plates were put into a Vitek MS Axima Assurance mass spectrometer (bioMerieux, Firenze, Italy) in positive linear mode at a laser frequency of 
$50 \mathrm{~Hz}$ with an acceleration voltage of $20 \mathrm{kV}$ with an extraction delay time of $200 \mathrm{~ns}$. Mass spectra detected ranged from 2000 to $20,000 \mathrm{Da}$.

MALDI-TOF generated unique MS spectra for microorganisms that were transferred into the SARAMIS software (Spectral ARchive and Microbial Identification System - Database version V4.12 - Software year 2013, bioMerieux, Firenze, Italy) where they were compared to the database hosting the reference spectra and SuperSpectra of bacteria. The SARAMIS database contains over 25,000 spectra from 586 bacterial and fungal species [44].

Each strain was analyzed 3 times in distinct, separate runs. A percent probability, or confidence level, was calculated by the software algorithm. This value represents specific peaks between the generated spectrum and the database spectra of their similarity in terms of presence or absence. A perfect match between the sample spectrum and the unique spectrum of a single organism or bacterial group resulted in a confidence level of $99.9 \%$ ("excellent ID"). For confidence levels ranging from $>60 \%$ to $99.8 \%$, the identification was considered a "good ID" because the spectrum was adequately close to that of a reference spectrum, while for a value of $<60 \%$, "no identification" (no ID) was given [45].

\section{PCR identification}

All isolated Vibrio strains were subcultured from glycerol stock onto SNA (supplemented with 1\% $\mathrm{NaCl}$ ) and incubated at $37^{\circ} \mathrm{C}$ for $18 \pm 1 \mathrm{~h}$. According to UNI EN ISO 21872-1:2017, one well-isolated colony from each SNA plate utilizing an inoculating loop was suspended in $500 \mu \mathrm{l}$ of sterile saline solution $(0.85 \% \mathrm{NaCl})$ in a $1.5 \mathrm{ml}$ microcentrifuge tube. DNA extraction was implemented with a heat treatment in Thermomixer (Eppendorf, Hamburg, Germany) registered at $95^{\circ} \mathrm{C}$ for $5 \mathrm{~min}$. After this treatment, the tubes were centrifugated at 10,000 rpm for $1 \mathrm{~min}$, and the supernatant was removed for PCR testing and stored at $-20^{\circ} \mathrm{C}$ until use. DNA concentration was estimated spectrophotometrically (SmartSpec Plus, Bio-Rad, Milan, Italy).

All biochemically identified strains were identified to proper genera through amplification utilizing PCR of the gene rpoA that codifies for the RNA polymerase alpha subunit, as mentioned by Dalmasso et al. [46]. The PCR reactions were conducted in a $50 \mu \mathrm{L}$ volume consisting of $0.5 \mu \mathrm{g}$ of purified genomic DNA, 25 pmol of each primer, 1x PCR buffer, $2 \mathrm{mM}$ $\mathrm{MgCl}_{2}, 0.2 \mathrm{mM}$ each of the dNTPs (Invitrogen,
Paisley, UK), and $1 \mathrm{U}$ of recombinant Taq DNA polymerase (Invitrogen, Paisley, UK).

The confirmations of $V$. cholerae were performed according to UNI EN ISO 21872-1:2017 [47] by the detection of the $\mathrm{prVC}$ target region [48]. DNA amplification was performed in a thermocycler (C1000 Touch, Bio-Rad, Italy) utilizing an initial denaturation step at $96^{\circ} \mathrm{C}$ for $5 \mathrm{~min}$ followed by 30 cycles of amplification (denaturation at $94^{\circ} \mathrm{C}$ for 1 min, annealing at $63^{\circ} \mathrm{C}$ for $1.5 \mathrm{~min}$, and extension at $72^{\circ} \mathrm{C}$ for $1.5 \mathrm{~min}$ ), ending with a final extension at $72^{\circ} \mathrm{C}$ for $7 \mathrm{~min}$.

Five microliters of each amplicon were loaded into 2\% agarose gel (Sigma-Aldrich, Italy) and subjected to linear electrophoresis at $90 \mathrm{~V}$ for $40 \mathrm{~min}$. Gels were imaged using a UV transilluminator (Gel Doc XR, Bio-Rad Laboratories, Hercules, USA) and analyzed utilizing Quantity One software (Bio-Rad Laboratories, Hercules, USA). A 100 bp DNA Ladder (Invitrogen Ltd., Paisley, UK) was utilized as a reference marker. For all PCR applications, a PCR mixture without DNA was used as a negative control and the reference strains Vibrio alginolyticus ATCC 17749 (for rpoA) and $V$. cholerae CCUG 3751 (for prVC) were used as positive controls. All primers were synthesized by Operon Technology (Cologne, Germany). The sequences of the primers used for amplification are listed in Table-3 $[46,48]$.

\section{Statistical analysis}

To evaluate significant differences among the samples in question, including fishery zones, species, and commercialized variants, one-way ANOVA and T-tests were carried out (Addinsoft, Microsoft Excel). The significance level was established as $\mathrm{p}<0.05$.

\section{Results and Discussion}

The application of the two ISO methods [41,42] permitted us to identify 42 strains as Vibrio spp. and to identify 15 strains as $V$. cholerae and 5 as $V$. fluvialis. The Noguerola and Blanch key [43] allowed our team to identify the remaining 22 strains ( $\mathrm{n}=20$ Vibrio alginolyticus and $\mathrm{n}=2 \mathrm{~V}$. hollisae) and to confirm their previous identification. The following MALDI-TOF analysis and PCR (rpoA and $p r V C$ ) tests validated the achieved results (Figure-2). All the isolated strains of $V$. cholerae were no-O1 and no-O139 and yielded negative results to the agglutination test with specific antisera.

Among 690 fishes analyzed, the 42 Vibrio strains were detected only in the cultured samples (from 42

Table-3: PCR primer used in the study.

\begin{tabular}{lllc}
\hline Gene target & Primer & Sequence & References \\
\hline$r p o A$ & rpoAf & Aaatcaggctcgggct & {$[46]$} \\
prVC & rpoAr & gcaatttt $(a / g) t c(a / g / t) a c(c / t) g g$ & {$[48]$} \\
& prVCf & ttaagcstttcrctgagaatg & \\
\hline
\end{tabular}

$\mathrm{PCR}=$ Polymerase chain reaction 
different fishes) (Tables-4 and 5). No Vibrio spp. were, in fact, detected among wild fishes. The farm setting may determine alterations in the chemical-physical parameters of the seawater such as to favor the cultivation of certain bacterial strains, including pathogens $[1,49]$. In addition, exposure to pathogens may be higher and more expansive in a farmed aquaculture setup than among wild fishes. Overall, 25 and 17 strains were isolated from cultured S. aurata and cultured D. labrax, respectively, without any significant difference ( $\mathrm{p}>0.05)$ (Table-4). In both species, V. alginolyticus, $V$. cholerae, and $V$. fluvialis were identified, while the two strains of $V$. hollisae were detected only in D. labrax.

The isolation of $V$. hollisae in fishes is uncommon due to the stringent growth conditions that cause typically low growth of these strains on selective media for Vibrio spp. such as those used in this study [13].

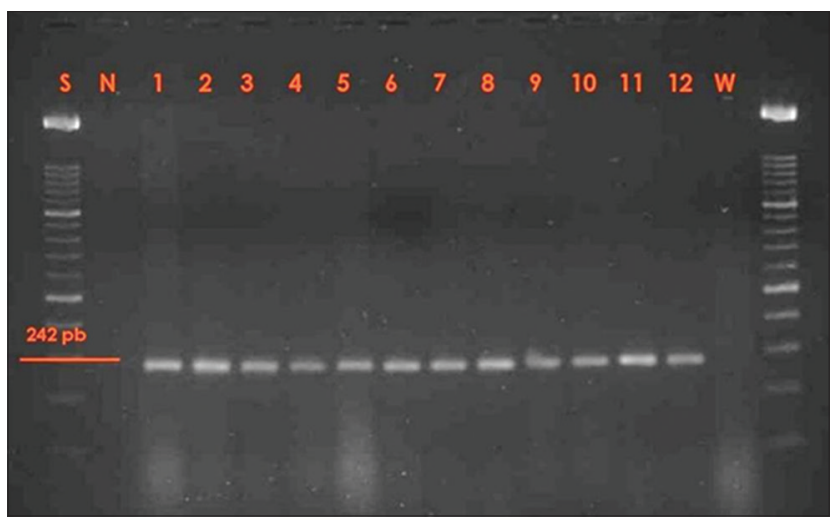

Figure-2: Agarose gel electrophoresis of the $r p o A(242 \mathrm{pb}$ ) amplification products of Vibrio strains. Lane S: Scale with 100 bp molecular size marker; lane N: Negative control (polymerase chain reaction mixture without DNA); lane 1: Positive control (Vibrio alginolyticus ATCC 17749); lanes 2-12: Positive samples; lane W: Water control.
Among these 42 strains, $V$. alginolyticus was the most representative species $(48 \%)$, followed by $V$. cholerae (36\%), V. fluvialis (12\%), and V. hollisae (4\%).

The recovery of Vibrio spp. was affected by the season in which they were sampled (Table-4). Among all the fishes, the largest amount $(\mathrm{n}=28)$ of strains was detected during the summer and principally in August (Table-5), while no Vibrio spp. were isolated from the samples collected during the spring (Table-4). Finally, 10 strains were harvested from fishes caught during the autumn and 4 strains were collected during the winter. This seasonal trend observed may be related to the increase in temperature and salinity of seawater during the summer season, stimulating Vibrio growth. The limited recovery of Vibrio spp. in winter is related to their ability to remain quiescent, in a viable but non-culturable state, while retaining their virulence [50].

Considering the sampling area, the largest number $(n=26)$ of strains was isolated from cultured fishes in the Boumerdes area (F1 and F2), while 16 strains were isolated from the farmed fishes sampled in the Tipaza area (F4). No Vibrio spp. occurred in the farm location F3 situated in the Azefoune area. The prevalence and distribution of the strains may be related to the farm setting and may also be related to the degree of seawater contamination. The presence of industrial plants and certain discharges in proximity to the farms may lead to favorable conditions for Vibrio growth, especially during the summer months when seawater is warmer. Therefore, the high level of contamination of Vibrio found in this area may also explain the detection of $V$. alginolyticus and $V$. cholerae strains during the winter season when, usually, the isolation of cultivable forms is rare $[28,32,51]$. From the Boumerdes area, 17 strains were isolated from farm F1, while 9 strains were isolated from farm F2. Interesting to note

Table-4: Distribution of Vibrio strains isolated in farmed D. labrax and S. aurata in relation to the season.

\begin{tabular}{|c|c|c|c|c|c|c|c|c|c|c|}
\hline \multirow[t]{2}{*}{ Strain } & \multirow[t]{2}{*}{ Season } & \multicolumn{4}{|c|}{ S. aurata } & \multicolumn{4}{|c|}{ D. labrax } & \multirow[t]{2}{*}{ Total } \\
\hline & & $\mathbf{F 1}$ & $\mathbf{F 2}$ & F3 & F4 & $\mathbf{F 1}$ & F2 & F3 & F4 & \\
\hline \multirow[t]{4}{*}{ V. alginolyticus } & Winter & 1 & 0 & 0 & 0 & 1 & 0 & 0 & 0 & 2 \\
\hline & Spring & 0 & 0 & 0 & 0 & 0 & 0 & 0 & 0 & 0 \\
\hline & Summer & 3 & 4 & 0 & 2 & 2 & 0 & 0 & 2 & 13 \\
\hline & Autumn & 1 & 1 & 0 & 1 & 1 & 0 & 0 & 1 & 5 \\
\hline \multirow[t]{4}{*}{ V. cholerae } & Winter & 1 & 0 & 0 & 0 & 1 & 0 & 0 & 0 & 2 \\
\hline & Spring & 0 & 0 & 0 & 0 & 0 & 0 & 0 & 0 & 2 \\
\hline & Summer & 2 & 4 & 0 & 1 & 2 & 0 & 0 & 1 & 0 \\
\hline & Autumn & 0 & 0 & 0 & 2 & 0 & 0 & 0 & 1 & 10 \\
\hline \multirow[t]{4}{*}{ V. fluvialis } & Winter & 0 & 0 & 0 & 0 & 0 & 0 & 0 & 0 & 3 \\
\hline & Spring & 0 & 0 & 0 & 0 & 0 & 0 & 0 & 0 & 0 \\
\hline & Summer & 0 & 0 & 0 & 1 & 0 & 0 & 0 & 2 & 0 \\
\hline & Autumn & 0 & 0 & 0 & 1 & 0 & 0 & 0 & 1 & 3 \\
\hline \multirow[t]{4}{*}{ V. hollisae } & Winter & 0 & 0 & 0 & 0 & 0 & 0 & 0 & 0 & 0 \\
\hline & Spring & 0 & 0 & 0 & 0 & 0 & 0 & 0 & 0 & 0 \\
\hline & Summer & 0 & 0 & 0 & 0 & 2 & 0 & 0 & 0 & 2 \\
\hline & Autumn & 0 & 0 & 0 & 0 & 0 & 0 & 0 & 0 & 0 \\
\hline Total & & 8 & 9 & 0 & 8 & 9 & 0 & 0 & 8 & 42 \\
\hline
\end{tabular}

S. aurata =Sparus aurata, D. labrax=Dicentrarchus labrax, V. alginolyticus=V. alginolyticus, V. cholerae=Vibrio cholerae, V. fluvialis=Vibrio fluvialis, $V$. hollisae=Vibrio hollisae 


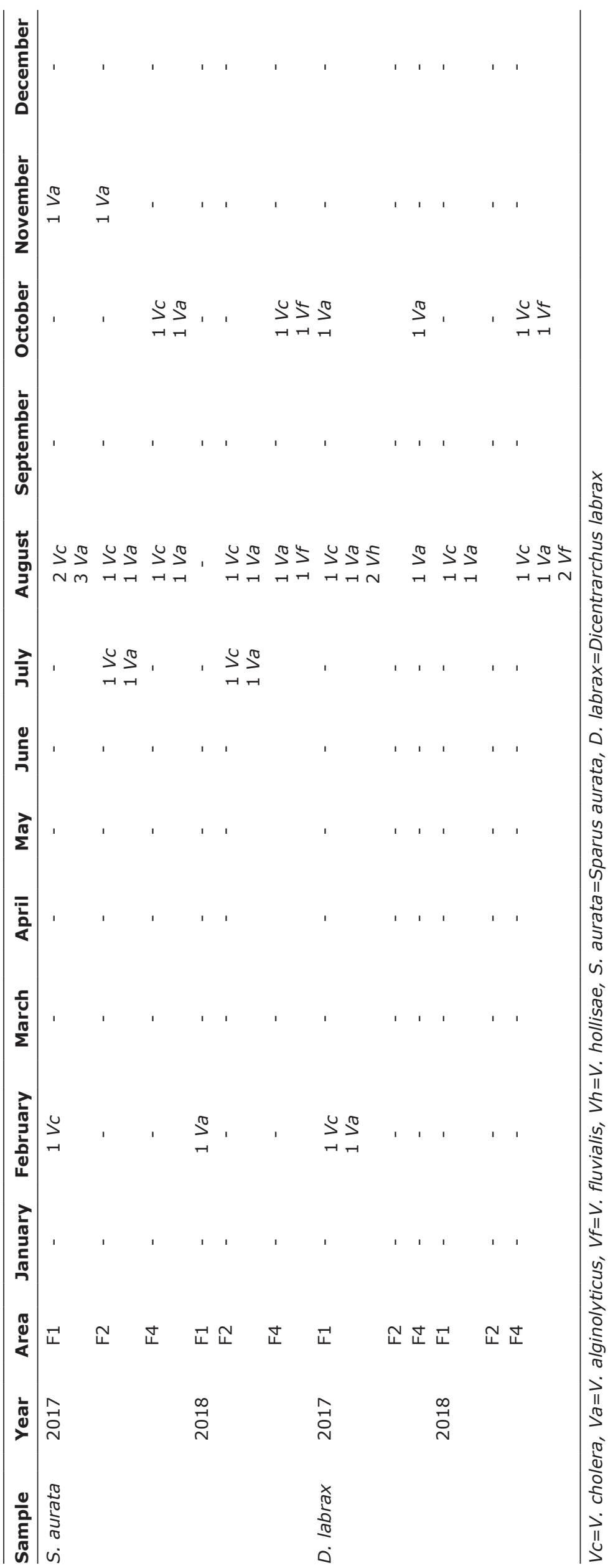


is that both these two farms receive wastewater from neighboring industrial plants and differ only in their specific farm setup. The land-based setting of F1 may be related to the greater number of isolated samples than found in F2, having a positive impact on Vibrio growth therein. Instead, no Vibrio strains were isolated from fishes caught in Azefoune.

The incidence rate of Vibrio spp. considering all the 690 fishes analyzed was $6.08 \%$ while, among the 530 cultured fishes, the percentage increased up to $7.92 \%$. The results obtained are consistent with a similar study conducted in Morocco on 220 samples of fishery products, where $8.2 \%$ of Vibrio spp. incidence was detected [14]. However, our data are at odds with the sole study performed on different seafood collected in Algeria, in which only one strain was isolated out of 200 fish samples [49]. The high reported prevalence $(2.83 \%)$ of $V$. cholerae observed in the farmed fishes in our study represents a pressing concern, considering the potentially high pathogenicity of this strain responsible for important foodborne outbreaks $[52,53]$.

In addition, further attention should be paid to $V$. alginolyticus, an opportunistic pathogen in gilt head sea bream and humans [54-56], and to $V$. fluvialis, which is considered an important emerging pathogen[17]. All these pathogens could infect fishes subject to stress factors such as breeding and catching associated with predisposed factors like the increase in water temperature during the summer season. In this regard, some pathogens of Vibrio spp. are able to contaminate edible portions of fish directly during its conservation or indirectly in the handling of fish products $[55,57,58]$. Given the wide consumption of fishery products in Algeria and the low number of literature data on Vibrio spp. as pathogenic agents in Algeria and beyond, it is clearly important to understand their distribution in marine environments as well as to develop methodologies for detecting viable but non-culturable forms of these organisms [59].

\section{Conclusion}

The present work advances substantially, with a high number of samples $(n=690)$, the lacking and dated studies on the presence of pathogenic Vibrio along the Algerian Mediterranean coast in wild and farmed $S$. aurata and D. labrax. In fact, surveying, monitoring, and detecting pathogens in foods are the most crucial approaches to reduce, control, or prevent foodborne pathogenic diseases [60]. The reported incidence of Vibrio and the presence of potentially pathogenic strains such as $V$. cholerae raise particular concern among Algerian farmed fish consumption, especially considering the possibility of cross-contamination in food production and the increasing consumption of raw fish products (sushi and sashimi) and marinated fish products [61]. The respect of storing temperature $\left(0-2^{\circ} \mathrm{C}\right)$, the application of preservation techniques [62], alongside the use of decontaminating agents such as bacteriophages and natural compounds [63-65], could reduce the risks related to the consumption of these fish products. However, considering the growing expansion of Algerian fish farms production and the tangential increase in the number of consumers exposed to potentially pathogenic Vibrio spp., the improvement and monitoring of hygienic farm conditions are highly necessary for food safety improvements.

\section{Authors' Contributions}

$\mathrm{SA}$ and $\mathrm{AB}$ conceived the study designed. SA performed the experiment. FG and LN analyzed the data. FG and LN drafted and revised the manuscript. All authors read and approved the final manuscript.

\section{Acknowledgments}

Facilities were supported by the Institut des Sciences Vétérinaires, Laboratoire de Recherche de Biotechnologies liées à la Reproduction Animale, University of Saad Dahlab - Blida, Algeria and by Department of Veterinary Sciences, University of Messina, Italy. This research did not receive any specific grant from funding agencies in the public, commercial, or not-for-profit sectors.

\section{Competing Interests}

The authors declare that they have no competing interests.

\section{Publisher's Note}

Veterinary World remains neutral with regard to jurisdictional claims in published map and institutional affiliation.

\section{References}

1. Gomez-Gil, J., Thompson, F.L., Thompson, C.C., GarciaGasca, A., Roque, A. and Swings, J. (2004) Vibrio hispanicus sp. nov. isolated from Artemia sp. and seawater in Spain. Int. J. Syst. Evol. Microbiol., 54(1): 261-265.

2. Hidalgo, R.B., Cleenwerck, I., Balboa, S., De wachter, M., Thompson, F.L., Swings, J., De Vos, P. and Romalde, J.L. (2008) Diversity of vibrios associated with reared clams in Galicia (NW Spain). Syst. Appl. Microbiol., 31(3): 215-222.

3. Balcazar, J.L., Gallo-Bueno, A., Palanas, M. and Pintado, J. (2010) Isolation of Vibrio alginolyticus and Vibrio splendidus from captive-bred seahorses with disease symptoms. Antonie van Leeuwenhoek, 97(2): 207-210.

4. Jones, J.L. (2017) Chapter 11-Vibrio. In: Dodd, C.E.R., Aldsworth, T., Stein, R.A., Cliver D.O. and Riemann, H.P., editors. Foodborne Diseases. $3^{\text {rd }}$ ed. Academic Press, United States. p243-252.

5. Lonappan, S., Golecha, R. and Nair, G.B. (2019) Contrasts, contradictions and control of cholera. Vaccine, 38(1): A4-A6.

6. Hara-Kudo, Y., Sugiyama, K., Nishibuchi, M., Chowdhury, A., Yatsuyanagi, J., Ohtomo, Y., Saito, A., Magnagano, H., Nishina, T., Nakagawa, H., Konuma, A., Miyahara, M. and Kumagai, S. (2003) Prevalence of pandemic thermostable direct hemolysin-producing Vibrio parahaemolyticus 03 : K6 in seafood and the coastal environment in Japan. Appl. Environ. Microbiol., 69(7): 3883-3891.

7. Baker-Austin, C., Stockley, L., Rangdale, R. and MartinezUrtaza, J. (2010) Environmental occurrence and clinical impact of Vibrio vulnificus and Vibrio parahaemolyticus: A 
European perspective. Environ. Microbiol. Rep., 2(1): 7-18.

8. Carburlotto, G., Haley, B.J., Lleo, M.M., Huq, A. and Colwell, R. (2010) Serodiversity and ecological distribution of Vibrio parahemolyticus in the Venetian Lagoon, Northeast Italy. Environ. Microbiol. Rep., 2(1): 151-157.

9. Wetz, J.J., Blackwood, A.D., Fries, J.S., Williams, Z.F. and Noble, R.T. (2014) Quantification of Vibrio vulnificus in an estuarine environment: A multi-year analysis using QPCR. Estuaries Coast, 37(2): 421-435.

10. Oliver, J.D. (2015) The biology of Vibrio vulnificus. Microbiol. Spectr., 3(3).

11. Baker-Austin, C., Trinanes, J., Gonzalez-Escalona, N. and Martinez-Urtaza, J. (2017) Non-cholera Vibrios: The microbial barometer of cli-mate change. Trends Microbiol., 25(1): 76-84.

12. Deeb, R., Tufford, D., Scott, G.I., Moore, J.G. and Dow, H. (2018) Impact of climate change on Vibrio vulnificus abundance and exposure risk. Estuaries Coast, 41(8): 2289-2303.

13. Gras-Rouzet, S., Donnio, P.Y., Juguet, F., Plessis, P., Minet, J. and Avril, J.L. (1996) First European case of gastroenteritis and bacteremia due to Vibrio hollisae. Eur. J. Clin. Microbiol. Infect. Dis., 15(11): 864-866.

14. Cohen, N., Karib, H., Ait Saïd, J., Lemee, L., Guenole, A. and Quilici, M.L. (2007) Prévalence des vibrions potentiellement pathogènes dans les produits de la pêche commercialisés à Casablanca (Maroc). Revue Méd. Vét., 158(11): 562-568

15. Pengsuk, C., Longyant, S., Rukpratanporn, S., Chaivisuthangkura, P., Sridulyakul, P. and Sithigorngul, P. (2010) Development of monoclonal antibodies for simple detection and differentiation of Vibrio mimicus from $V$. cholerae and Vibrio spp. by dot blotting. Aquaculture, 300(1-4): 17-24.

16. Sabir, M., Moulay, M.E. and Nozha, C. (2013) Vibrio alginolyticus: An emerging pathogen of foodborne diseases. Maejo Int. J. Sci. Technol., 2(4): 302-309.

17. Ramamurthy, T., Chowdhury, G., Pazhani, G.P. and Shinoda, S. (2014) Vibrio fluvialis: An emerging human pathogen. Front. Microbiol., 5(91): 1-9.

18. Bonadonna, L., Briancesco, R., Suffredini, E., Coccia, A., Libera, S.D., Verani, M., Federigi, I., Iaconelli, M., Ferraro, G.B., Mancini, P., Carducci, A., Veneri, C., Lucentini, L., Gramaccioni, L., La Rosa, G. and Ferretti, E. (2019) Enteric viruses, somatic coliphages and Vibrio species in marine bathing and non-bathing waters in Italy. Mar. Pollut. Bull., 149: Article ID 110570.

19. Bakhrouf, A., Jeddi, M. and Ben Ouada, H. (1995) Essai de traitement des vibrioses du loup Dicentrarchus labrax dans une zone de pisciculture, à Monastir, Tunisie. Mar. Life, $5(2): 47-54$

20. Zorilla, I., Moriñigo, M.A., Castro, D., Balebona, M.C. and Borrego, J.J. (2003) Intraspecific characterization of Vibrio alginolyticus isolates recovered from cultured fish in Spain. J. Appl. Microbiol., 95(5): 1106-1116.

21. Gomez-Léon, J., Villamil, L., Lemos, M.L., Novoa, B. and Figueras, A. (2005) Isolation of Vibrio alginolyticus and Vibrio splendidus from aquacultured carpet shell clam (Ruditapes decussatus) larvae associated with mass mortalities. Appl. Environ. Microbiol., 71(1): 98-104.

22. Frans, I., Michiels, C.W., Bossier, P., Willems, K.A., Lievens, B. and Rediers, H. (2011) Vibrio anguillarum as a fish pathogen: Virulence factors, diagnosis and prevention. J. Fish Dis., 34(9): 643-661.

23. Scarano, C., Spanu, C., Ziino, G., Pedonese, F., Dalmasso, A., Spanu, V., Virdis, S. and De Santis, E.P.L. (2014) Antibiotic resistance of Vibrio species isolated from Sparus aurata reared in Italian mariculture. New Microbiol., 37(3): 329-337.

24. FAO/WHO. (2002) Food Safety Consultation, Risk Assessment of Campylobacter spp. in Broiler Chickens and Vibrio spp. in Seafood, Report of a Joint FAO/WHO Expert Consultation. FAO/WHO, Bangkok, Thailand. p59.
25. Gonzalez, S.F., Krug, M.J., Nielsen, M.E., Santos, Y. and Call, D.R. (2004) Simultaneous detection of marine fish pathogens by using multiplex PCR and DNA Microarray. $J$. Clin. Microbiol., 42(4): 1414-1419.

26. Baker-Austin, C., Trinanes, J.A., Taylor, N.G.H., Hartnell, R., Siitonen, A. and Martinez-Urtaza, J. (2013) Emerging Vibrio risk at high latitudes in response to ocean warming. Nat. Rep. Clim. Change, 3(1): 73-77.

27. Vezzulli, L., Grande, C., Reid, P.C., Hélaouët, P., Edwards, M., Höfle, M.G., Brettar, I., Colwell R.R. and Pruzzo, C. (2016) Climate influence on Vibrio and associated human diseases during the past half-century in the coastal North Atlantic. Proc. Natl. Acad. Sci. U. S. A., 113(34): E5062-E5071.

28. Thompson, J.R., Randa, M.A., Marcelino, L.A., TomitaMitchell, A., Lim, E. and Polz, M.F. (2004) Diversity and dynamics of a North Atlantic coastal Vibrio community. Appl. Environ. Microbiol., 70(7): 4103-4110.

29. Tantillo, G., Fontanarosa, M., Di Pinto, A. and Musti, M. (2004) Update perspectives on emerging Vibrios associated with human infections. Lett. Appl. Microbiol., 39(2): 117-126.

30. McLaughlin, J.B., DePaola, A., Bopp, C.A., Martinek, K.A., Napolilli, N.P., Allison, C.G., Murray, S.L., Thompson, E.C., Bird, M.M. and Middaugh, J.P. (2005) Outbreak of Vibrio parahaemolyticus gastroenteritis associated with Alaskan oysters. N. Engl. J. Med., 353(14): 1463-1470.

31. FAO/WHO. (2011) Risk Assessment of Vibrio parahaemolyticus in Seafood. FAO/WHO, Canada. p183.

32. Lhafi, S.K. and Kühne, M. (2007) Occurrence of Vibrio sp. in blue mussels (Mytilus edulis) from the Germen Wadden Sea. Food Microbiol., 116(2): 297-300.

33. Froelich, B., Gonzalez, R., Blackwood, D., Lauer, K. and Noble, R. (2019) Decadal monitoring reveals an increase in Vibrio spp. Concentrations in the Neuse River Estuary, North Carolina, USA. PLoS One, 14(4): e0215254.

34. Ziino, G., Donato, G., Giarratana, F., Giuffrida, A. and Panebianco, A. (2014) Bacteriological analysis to Arca noae (Linnaeus, 1758) in the South of Italy: The first record of halophilic Vibrio. Cah. Biol. Mar., 55(4): 389-397.

35. FAO. (2018) Food and Agriculture Organization of the United State-fisheries and Aquaculture Department. National Aquaculture Sector Overview. Algeria. Available from: http://www.fao.org/fishery/countrysector/naso_algeria/en. Retrieved on 04-11-2019.

36. Jaroslaw, A. (2018) Algerian Aquaculture: Poised for Growth. Available from: https://www.thefishsite.com/articles/algerian-aquaculture-poised-for-growth. Retrieved on 06-11-2019.

37. Zorrilla, I., Arijo, S., Chabrillon, M., Diaz, P., MartinezManzanares, E., Balebona, M.C. and Morinigo, M.A. (2003) Vibrio species isolated from diseased farmed sole, Solea senegalensis (Kaup), and evaluation of the potential virulence role of their extracellular products. J. Fish Dis., 26(2): 103-108.

38. Kahla-Nakbi, A.B., Chaieb, K. and Bakhrouf, A. (2009) Investigation of several virulence properties among Vibrio alginolyticus strains isolated from diseased cultured fish in Tunisia. Dis. Aquat. Organ., 86(1): 21-28.

39. Al-Sunaiher, A.E., Ibrahim, A.S.S. and Al-Salamah, A.A. (2010) Association of Vibrio species with disease incidence in some cultured fishes in the Kingdom of Saudi Arabia. World Appl. Sci. J., 8(5): 653-660.

40. Rameshkumar, P., Nazar, A.K.A., Pradeep, M.A., Kalidas, C., Jayakumar, R., Tamilmani, G., Sakthivel, M., Samal, A.K., Sirajudeen, S., Venkatesan, V. and Nazeera, B.M. (2017) Isolation and characterization of pathogenic Vibrio alginolyticus from sea cage cultured cobia (Rachycentron canadum (Linnaeus 1766)) in India. Lett. Appl. Microbiol., 65(5): 423-430.

41. ISO/TS 21872-1:2007. (2007) Microbiology of Food and Animal Feeding Stuffs-horizontal Method for the 
Detection of Potentially Enteropathogenic Vibrio spp.-Part 1: Detection of Vibrio parahaemolyticus and Vibrio cholerae. International Organization for Standardization, United Kingdom.

42. ISO/TS 21872-2:2007. (2007) Microbiology of Food and Animal Feeding Stuffs-horizontal Method for the Detection of Potentially Enteropathogenic Vibrio spp.-Part 2: Detection of Species other than Vibrio parahaemolyticus and Vibrio cholerae. International Organization for Standardization, United Kingdom.

43. Noguerola, I. and Blanch, A.R. (2008) Identification of Vibrio spp. with a set of dichotomous keys. J. Appl. Microbiol., 105(1): 175-185.

44. Mattei, R., Vicario, C., Nardone, M. and Savarino, A. (2012) Evaluation of the system axima/saramis MALDI-TOF MS BioMérieux in a clinical laboratory. Microbiol. Med., 27(1): 34-37.

45. Dubois, D., Grare, M., Prere, M.F., Segonds, C., Marty, N. and Oswald, E. (2012) Performances of the Vitek MS matrix-assisted laser desorption ionization-time of flight mass spectrometry system for rapid identification of Bacteria in routine clinical microbiology. J. Clin. Microbiol., 50(8): 2568-2576.

46. Dalmasso, A., La Neve, F., Suffredini, E., Croci, L., Serracca, L., Bottero, M.T. and Civera, T. (2009) Development of a PCR assay targeting the rpoA gene for the screening of Vibrio genus. Food Anal. Methods, 2(4): 317-324.

47. ISO 21872-1:2017. (2017) Microbiology of Food Chainhorizontal Method for the Detection of Potentially Enteropathogenic Vibrio spp.-Part 1: Detection of Potentially Enteropathogenic Vibrio parahaemolyticus, Vibrio cholerae and Vibrio vulnificus. International Organization for Standardization, United Kingdom.

48. Chun, J., Huq, A. and Colwell, R.R. (1999) Analysis of 16S-23S rRNA intergenic spacer regions of Vibrio cholerae and Vibrio mimicus. Appl. Environ. Microbiol., 65(5): 2202-2208.

49. Dib, A. (2008) Evaluation de la Contamination des Produits de la mer par les Vibrio Dans la region de l'Est Algerien. Mémoire de Magistère, 2007/2008. Ecole Nationale Vétérinaire d'EL Harach, Algeria.

50. Oliver, J.D. (2016) The viable but nonculturable state for Bacteria: Status update. Microbe, 11(4): 159-164.

51. Miossec, L. (2002) Les vibrions pathogènes pour l'homme: Le risque associé au milieu Marin en France. Ifremer, 2002: 21-22.

52. Hill, V.R., Cohen, N., Kahler, A.M., Jones, J.L., Bopp, C.A., Marano, N., Cheryl, T.L., Garrett, N.M., Boncy, J., Henry, A., Gómez, G.A., Wellman, M., Curtis, M., Freeman M.M., Turnsek, M., Benner, R.A., Dahourou, G., Espey, D., DePaola, A. Tappero, J.W., Handzel, T. and Tauxe, R.V. (2011) Toxigenic Vibrio cholerae O1 in water and seafood, Haiti. Emerg. Infect. Dis., 17(11): 2147-2150.
53. Samanta, M. and Choudhary, P. (2019) Safety of fish and seafood. In: Food Safety and Human Health. Academic Press, United States. p169-187.

54. Baskaralingam, V., Sargunar, C.G., Lin, Y.C. and Chen, J.C. (2012) Green synthesis of silver nanoparticles through Calotropis gigantea leaf extracts and evaluation of antibacterial activity against Vibrio alginolyticus. Nanotechnol. Dev., 2(1): e3.

55. Liu, X.F., Zhang, H., Liu, X., Gong, Y., Chen, Y., Cao, Y. and $\mathrm{Hu}, \mathrm{C}$. (2014) Pathogenic analysis of Vibrio alginolyticus infection in a mouse model. Folia Microbiol., 59(2): 167-171.

56. Castillo, D., D'Alvise, P., Kalatzis, P.G., Kokkari, C., Middelboe, M., Gram, L., Liu, S. and Katharios, P. (2015) Draft genome sequences of Vibrio alginolyticus strains V1 and V2, opportunistic marine pathogens. Genome Announc., 3(4): e00729-15.

57. Albert, M.J., Neira, M. and Motarjemi, Y. (1997) The role of food in the epidemiology of cholera. World Health Stat. Q., 50(1-2): 111-118.

58. Vengadesh, L., Son, R. and Yoke-Kqueen, C. (2012) Molecular quantitation and characterization of Vibrio cholerae from different seafood obtained from wet market and supermarket. Int. Food Res. J., 19(1): 45-50.

59. Mougin, J., Copin, S., Bojolly, D., Raguenet, V., RobertPillot, A., Quilici, M.L., Midelet-Bourdin, G., Grard, T. and Bonnin-Jusserand, M. (2019) Adhesion to stainless steel surfaces and detection of viable but non cultivable cells of Vibrio parahaemolyticus and Vibrio cholerae isolated from shrimps in seafood processing environments: Stayin' alive? Food Control, 102: 122-130.

60. Zhao, X., Lin, C.W., Wang, J. and Oh, D.H. (2014) Advances in rapid detection methods for foodborne pathogens. J. Microbiol. Biotechnol., 24(3): 297-312.

61. Muscolino, D., Giarratana, F., Beninati, C., Tornanbene, A., Panebianco, A. and Ziino, G. (2014) Hygienic-sanitary evaluation of sushi and sashimi sold in Messina and Catania, Italy. Ital. J. Food Saf., 3(2): 1701.

62. Ronholm, J., Lau, F. and Banerjee, S.K. (2016) Emerging seafood preservation techniques to extend freshness and minimize Vibrio contamination. Front. Microbiol., 7: 350.

63. Acevedo, J.A., López, J.M., Cortés, A.M., Bores, A.G., Cortés, G.M. and Castro, I.P. (2005) In vitro anti-Vibrio cholerae activity of essential oil from Lepechinia caulescens. Fitoterapia, 76(1): 104-107.

64. Hajlaoui, H., Mighri, H., Noumi, E., Snoussi, M., Trabelsi, N., Ksouri, R. and Bakhrouf, A. (2010) Chemical composition and biological activities of Tunisian Cuminum cyminum L. essential oil: A high effectiveness against Vibrio spp. Strains. Food Chem. Toxicol., 48(8-9): 2186-2192.

65. Plaza, N., Castillo, D., Pérez-Reytor, D., Higuera, G., García, K. and Bastías, R. (2018) Bacteriophages in the control of pathogenic vibrios. Electron. J. Biotechnol., 31 : 24-33. 